\title{
Nanofibrous Vildagliptin-Eluting Stents Enhance Re-Endothelialization And Reduce Neointimal Formation In Diabetes: In Vitro And In Vivo [Corrigendum]
}

\author{
Lee $\mathrm{CH}$, Hsieh $\mathrm{MJ}$, Chang $\mathrm{SH}$, et al. Int $J$ Nano. \\ 2019;14:7503-7513.
}

The authors noticed a mistake in the published paper which was overlooked during the revision stages.

On page 7511, in the Acknowledgments section, the sentence “... Chang Gung Memorial Hospital (Contract
No. CMRPG3G1291) for financially supporting this research." should read “... Chang Gung Memorial Hospital (Contract No. CMRPG3G1291 and CMRPG3G1292) for financially supporting this research."

The authors apologize for this oversight.

\section{Publish your work in this journal}

The International Journal of Nanomedicine is an international, peerreviewed journal focusing on the application of nanotechnology in diagnostics, therapeutics, and drug delivery systems throughout the biomedical field. This journal is indexed on PubMed Central, MedLine, CAS, SciSearch ${ }^{\circledR}$, Current Contents ${ }^{\circledR} /$ Clinical Medicine,
Journal Citation Reports/Science Edition, EMBase, Scopus and the Elsevier Bibliographic databases. The manuscript management system is completely online and includes a very quick and fair peer-review system, which is all easy to use. Visit http://www.dovepress.com/ testimonials.php to read real quotes from published authors. 